\title{
Effect of Cumulus Cells on the Development of Bovine Oocytes Matured and Fertilized in Vitro
}

\author{
Naokazu Takada, Akio Tsukamoto ${ }^{1)}$, Yousuke Kurokawa ${ }^{2)}$, and Yasuo Shioya ${ }^{3)}$ \\ Miyagi Prefectural Animal Industry Experiment Station, Iwadeyama-cho 989-64, \\ ${ }^{1)}$ Okayama Prefectural Center for Animal Husbandry, Osa-cho 719-35, \\ ${ }^{2)}$ Saga Prefectural Livestock Experiment Station, Yamauchi-cho 849-23, and \\ ${ }^{3)}$ National Institute of Animal Industry, Tsukuba Norinkenkyudanchi, P.O. Box 5, Ibaraki-ken 305
}

(Accepted for publication August 20, 1990)

\begin{abstract}
Summary. Effect of the contact between embryos and cumulus cell monolayers on the development of 8-16 cell bovine embryos to blastocysts was investigated in IVF system. In vitro matured oocytes were inseminated by frozen-thawed sperm capacitated with heparin. After $72 \mathrm{hr}$ of the insemination, oocytes were removed from cumulus cells and embryos developed to 8-16 cell stage were cultured for eight days after insemination under three different conditions; i.e. (i) direct contact: the embryos were directly placed on the cumulus cell monolayers, (ii) non-contact: a permeable filter was placed between embryos and the cumulus cell monolayers, (iii) without cumulus cells: the embryos were cultured without cumulus cell monolayers. Frozen-thawed semen from two bulls were used. The proportion of embryos developed to blastocyst stage (no. of blastocysts/no. of 8-16 cell embryos) were $32.9(23 / 70) \sim 36.9(24 / 65), 25.7(18 / 70) \sim 44.1(30 / 68)$ and $7.4(5 / 68) \sim 9.2 \%$ (6/65), respectively. The result showed that the direct contact of embryos with cumulus cell monolayers was not necessary for the expression of the co-culture effect on the development to blastocyst stage and suggested that the effect was due to diffusable factors.

KEY WORDS: BOVINE EMBRYOS, IN VITRO FERTILIZATION, CO-CULTURE, CUMULUS CELls.
\end{abstract}

Jpn J Anim Reprod 37, 9-13, 1991

\section{牛体外受精卵の発育に及ぼす卵丘細胞の影響}

\author{
高田 直和・塚本 章夫 ${ }^{1)} \cdot$ 黒川 洋介 ${ }^{2)} \cdot$ 塩谷 $\quad$ 康生 ${ }^{3)}$ \\ 宮城県畜産試験場 $\overline{7} 989-64$ 玉造郡岩出山町 \\ 1) 岡山県総合畜産センター $\mathbf{T} 719-35$ 阿哲郡大佐町

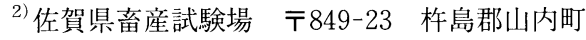 \\ ${ }^{3)}$ 農林水産省畜産試験場 $\quad$ T305 茨城県筑波農林研究団地内局私書箱 5 号
}

牛の体内及び体外受精卵を卵のみで体外で培養すると 8-16細胞期で発生が停止する（Thibault, 1966; Camous et al., 1984; Eystone and First, 1986). 同様の発生停止 はヒッジでは8-16細胞期に (Bondioli and Wright, 1980) ブタでは 4 細胞期に (Davis, 1985)，マウスでは 2 細胞 期に (Whittingham and Biggers, 1967) 起こることが 報告されている。しかしながら牛の体外受精卵は, 卵丘
細胞 (Fukuda et al., 1987) や, 卵管上皮細胞 (Eystone et al., 1987) もしくは栄養外胚葉 (Nakao et al., 1988) のいずれかで共培養すると肧盤胞まで発育させることが できる。牛体外受精卵が、卵丘細胞と共培養することに よって, 胚盤胞まで発育する作用機構については，未だ 不明であるが，今のところ，胚が卵丘細胞層と接触する ことによる物理的因子によるものか, あるいは液性因子 
によるものかの二点が考えられる。本実験では，牛体外 受精卵を卵丘細胞層と接触させずに共培養する方法を考 案し，その後の胚の発育を調べた。

\section{材料と方法}

未成熟卵の採取と体外成熟：ホルスタイン種の卵巣を食 肉処理場において屠畜直後に採取した。卵巣は抗生物質 (ペニシリン $100 \mathrm{U} / \mathrm{ml}$ ，ストレプトマイシン $100 \mu \mathrm{g} / \mathrm{ml}$, 明治製菓) を加え $38 \sim 39^{\circ} \mathrm{C}$ に温めた生理的食塩水に入れ て実験公に運び， $5 \mathrm{~mm}$ 以下の小卵胞から卵子を吸引採 取した。卵子の吸引には, 抗生物質と $3 \mathrm{mg} / \mathrm{ml}$ の牛血 清アルブミン（BSA）を加えた修正リン酸緩衝液の少 量を18Gの針を付けた $5 \mathrm{ml}$ の注射器に吸引したものを 使用した。緊密な卵丘細胞層が付着している卵子のみを 選抜し, 流動パラフィンで覆った $100 \mu \mathrm{l}$ の培養液中に 10 個ずつ入れ， $5 \%$ 炭素ガス, $95 \%$ 空気, $39^{\circ} \mathrm{C}$ の炭素ガス 培養器に入れ $20 〜 24$ 時間培養した. 成熟培地は, 25 $\mathrm{mM}$ へペス緩衝 TCM199（GIBCO）に, 非働化子牛血

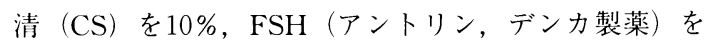
$2 \mu \mathrm{g} / \mathrm{ml}$ ，エストラジオール-17 $\beta$ (Sigma) を $1 \mu \mathrm{g} / \mathrm{ml}$ 加えて用いた.

体外受精 : 精子は 2 頭の黒毛和種の凍結精液を用いた. 融解後, BSAを除いた修正夕イロード液（BO 液, Brackett and Oliphant, 1975) にカフェイン（安息香酸 ナトリウムカフェイン中のカフェインを $50 \%$ として計算, Sigma）を $10 \mathrm{mM}$ 加えた液（Caf-BO 液）で 2 回洗浄し た. 洗浄後, 精子濃度を Caf-BO 液で $20 \times 10^{6}$ 精子 $/ \mathrm{ml}$ に溒整した精子浮遊液を, BSA $20 \mathrm{mg} / \mathrm{ml}$ とへパリン $10 \mathrm{U} / \mathrm{ml}$ (ノボヘパリン注, ノボインダストリーA/S) を会む修正夕イロード液（Hep-BSA-BO 液）で等倍に 杀㗭した。この精子浮遊液を, $100 \mu \mathrm{l}$ の小滴にして流動 パラフィンで覆い, 炭素ガス培養器で15分間培養した。 体外成熟卵を Hep-BSA-BO 液で 2 回洗浄し, 精子浮遊 液に約50個ずつ導入した.

体外発育：卵子は媒精 6 時間後に発生培地に移した。発 生培地は, $25 \mathrm{mM}$ へペス緩衝 TCM199に非働化 CS10\%
を加え, 直径 $35 \mathrm{~mm}$ のプラスチックシャーレ (Nunc, Inter Med）に $4 \mathrm{ml}$ 分注し, 流動パラフィンで覆って用 いた。1シャーレあたりの卵子数は，50〜100個とした。 一部の卵子を媒精18時間後に抜き取り，標本にして精子 進入状況を検査した。媒精72時間後, 卵子を卵丘細胞か ら取り外し，卵分割状況を検査するとともに，8-16細胞 期に発育した胚を以下の 3 区に分けて媒精後 8 日目まで 培養を続けた。

接触区;8-16細胞期胚を, 卵丘細胞が単層状に発育した シャーレに入れて培養した。

非接触区; 底面が $0.4 \mu \mathrm{m}$ のフィルターの円筒形セル (Millicell-HA，ミリポア社) に胚を入れ，このセルを接 触区と同様に卵丘細胞が単層状に発育したシャーレに入 れて培養した。

非共培養区; 新しいシャーレに発生培地を $4 \mathrm{ml}$ 入れて胚 を培養した。いずれの区においても媒精後 8 日目に肧盤 胞への発育を検査した。

脱出胚盤胞への発育：媒精後 8 日目までに出現した胚盤 胞はすべて，接触区と同様に卵丘細胞層の上に置いてさ らに48時間培養し，脱出胚盤胞への発育率を調べた.

統計処理：差の検定は， $\chi^{2}$ 検定によった.

\section{結 果}

媒精18時間で抜き取って調べた受精率は, 精子Aで $93.3(14 / 15) \sim 100 \%(17 / 17)$, 精子 B で 94.1 (16/17) 100\% (17/17) と良好であった。体外受精卵の発生率を表 1 に示した。 2 細胞期以上への発生率は $43.3 \sim 59.6 \%$, 8-16細胞期への発生率は22.7〜29.6\%であった.8-16細 胞期胚を卵丘細胞層と接触あるいは接触させないで培養 した場合の胚盤胞への発育率（肧盤胞数／供試8-16細胞 期胚数）を表 2 に示した。接触区，非接触区および非共 培養区における胚盤胞への発育率は, それぞれ 32.9 $(23 / 70) \sim 36.9(24 / 65), 25.7(18 / 70) \sim 44.1(30 / 68)$ およ び7.4(5/68) ９.2\%(6/65) であり, 非共培養区で有意 に低かった $(\mathrm{P}<0.01)$. 発育した肧盤胞の媒精後 8 日 目以降における脱出胚盤胞への発育率（脱出肧盤胞数 $/$

Table 1. In vitro development of bovine embryos following in vitro maturation and fertilization

\begin{tabular}{ccccc}
\hline \hline Bull & No. of oocytes & Trials & $\begin{array}{c}\text { No. of oocytes } \\
\text { cleaved }(\%)\end{array}$ & $\begin{array}{c}\text { No. of oocytes developed } \\
\text { to } 8-16 \text { cell }(\%)\end{array}$ \\
\hline A & 984 & 5 & $426(43.3)$ & $223(22.7)$ \\
B & 840 & 4 & $501(59.6)$ & $249(29.6)$ \\
\hline
\end{tabular}


Table 2. Effect of co-culture with cumulus cells on development of 8-16 cell bovine embryos to blastocysts

\begin{tabular}{|c|c|c|c|c|}
\hline \multirow[b]{3}{*}{ Bull } & \multirow[b]{3}{*}{ Trials } & \multicolumn{3}{|c|}{ No. of embryos developed (\%) } \\
\hline & & \multicolumn{2}{|c|}{ Co-culture with cumulus cells } & \multirow{2}{*}{$\begin{array}{c}\text { Without cumulus } \\
\text { cells }\end{array}$} \\
\hline & & Direct contact & Non contact & \\
\hline A & 5 & $24 / 65(36.9)^{\mathrm{a})}$ & $30 / 68(44.1)^{a)}$ & $6 / 65(9.2)^{\mathrm{b})}$ \\
\hline $\mathrm{B}$ & 4 & $23 / 70(32.9)^{\mathrm{a})}$ & $18 / 70(25.7)^{\mathrm{a})}$ & $5 / 68(7.4)^{\mathrm{b})}$ \\
\hline
\end{tabular}

$\mathrm{P}<0.01 ; \mathrm{a}$ vs $\mathrm{b}$.

Table 3. Effect of co-culture with cumulus cells on hatching of blastocysts developed in vitro

\begin{tabular}{|c|c|c|c|c|}
\hline \multirow[b]{3}{*}{ Bull } & \multirow[b]{3}{*}{ Trials } & \multicolumn{3}{|c|}{ No. of hatched blastocysts/no. of blastocysts } \\
\hline & & \multicolumn{2}{|c|}{ Co-culture with cumulus cells } & \multirow{2}{*}{$\begin{array}{l}\text { Without cumulus } \\
\text { cells }\end{array}$} \\
\hline & & Direct contact & Non contact & \\
\hline A & 5 & $18 / 24(75.0)^{\mathrm{a})}$ & $22 / 30(73.3)^{\mathrm{a})}$ & $1 / 6(16.7)^{\mathrm{b})}$ \\
\hline B & 4 & $16 / 23(69.6)^{\mathrm{a})}$ & $13 / 18(72.2)^{\mathrm{a})}$ & $0 / 5\left(\begin{array}{ll}0 & \left.)^{\mathrm{b}}\right)\end{array}\right.$ \\
\hline
\end{tabular}

$\mathrm{P}<0.01 ;$ a vs b.

胚盤胞数）を表 3 に示した。接触区，非接触区および非 共培養区における脱出胚盤胞への発育率は, それぞれ $69.6(16 / 23) \sim 75.0(18 / 24), 72.2(13 / 18) \sim 73.3(22 / 30)$ および $0(0 / 5) \sim 16.7 \%(1 / 6)$ であり，非共培養区で有意 に低かった $(\mathrm{P}<0.01)$.

\section{考察}

牛体外受精によって得た8-16細胞期胚を卵丘細胞層に 接触あるいは接触させないで培養した結果, 接触してい ない場合でも接触している場合と同様の割合で肧盤胞に 発育することが明らかとなった.

牛体外受精卵を卵丘細胞と共培養すると胚盤胞へ高率 に発育することはすでに多数報告されている（Kajihara et al., 1987; Aoyagi et al., 1989; Berg and Brem, 1990). しかしながら, 胚盤胞への発育促進効果の原因はよく分 かっていない. Heymanら（1987）は, 生体から回収し た牛初期胚を，栄養外胚葉の断片と共培養すると， $46 \%$ が桑実胚に発育し，同組織を培養して得られた条件付け 培地によっても同様の結果が得られることを報告した. またEystone とFirst（1989）は，生体から回収した牛 初期胚を, 卵管上皮細胞と共培養すると, $43 \%$ が桑実胚 一胚盤胞に発育し, 条件付け培地でも同様の結果が得ら
れることを報告している，これらの実験結果は, 共培養 系に扮ける細胞の増殖支持作用が，液性因子であること を示唆するものである. 本実験結果は共培養に用いた細 胞の種類は異なり，また条件付け培地は用いなかったが, 胚の発育促進作用は液性因子であるとした彼らの報告を 支持するものであった。

胚の発育が液性因子により促進される機構は二点考え られる．第一点は卵丘細胞が胚の細胞増殖を促進する物 質を分泌するというものである. 卵胞細胞は progesterone と estradiol-17 $\beta$ の 2 種類のステロイドホルモン (Hamberger et al., 1978; Henderson et al., 1987), ピル ビン酸 (Donahue and Stern, 1968) や特異的蛋白 (Landefeld et al., 1979) を分泌していることが報告され ており,これらの物質が胚の発育を促進している可能性 が考えられる，第二点は卵丘細胞の代謝により培養液中 に含まれる胚の発育抑制物質が除去されるというもので ある，培養液中に含まれる発育抑制物質については，例 えば, Ham's F10に含まれる Hypoxanthine はマウスの 2-cell block（Loutradis, 1987）を, 修正タイロード液 に含まれる燐酸とグルコースはハムスターの2-cell block（Schini and Bavister, 1988）を起こすことが知ら れている. しかしながら,これらの仮説は現在のところ 
証明されてはいない.

胚盤胞への発育率に影響する要因として, 卵巣の個体 差 (Goto et al., 1990), 種雄牛の個体差 (Yamada et al., 1988), 発育培地に添加する血清の種類（Fujitani et al., 1987; Wang et al., 1989), 発育培地の量（Takuma et al., 1989)，共培養する細胞の濃度（Tokunaga and Tsunoda, 1989）などが報告されている．牛体外受精卵 を卵斥細胞と共培養した場合における胚盤胞への発生率 は，報告者により異なる（15.1\%：Goto et al., 1988; $22.2 \%$ :Jiang et al., 1989). 本実験で得られた, 接触区 における8-16細胞期胚の胚盤胞への発育率は，32.9 $36.9 \%$ でった。これは，供試した成熟卵に対する率と して考えてみると $7.3 \sim 8.2 \%$ とな.これはGotoら (1988) やJiang ら（1989）に比べると低率であったが, 供試した卵数（50〜100）に対して発育培地の量 $(4 \mathrm{ml})$ が多かったことによると考えられる。また媒精72時間で 8 細胞期に達しない胚を実験から除外したことも一因で ある. 除外した 8 細胞期以下の胚も肧盤胞に発育するか らである.

本実験結果から，牛体外受精卵を卵丘細胞と共培養し た場合における肧の発育促進効果は液性因子である可能 性が示唆された。今後は卵丘細胞を培養して得られた条 件付け培地を用いて実験を行う必要がある。またさらに 研究を重ねて, 細胞増殖因子を明らかにしてゆかねばな らない.

\section{謝辞}

卵菓採取に御協力いただいた筑西食肉公社及び茨城県 塄西食肉衛生検査所の方々に対して御礼申し上げます.

\section{文献}

Aoyagi Y, Fukui Y, Iwazumi Y, Urakawa M, Minegishi Y, Ono H (1989) Effect of culture system on development of in vitro fertilized bovine ova into blastocysts. Theriogenology 31: 168 (Abstr).

Berg U, Brem G (1990) Developmental rates of in vitro produced IVM-IVF bovine oocytes in different cell co-culture systems. Theriogenology 33: 195 (Abstr).

Bondioli KR, Wright RW Jr (1980) Influence of culture media on in vitro fertilization of ovine tubal oocytes. $J$ Anim Sci 51: 660-667.

Brackett BG, Oliphant G (1975) Capacitation of rabbit spermatzoa in vitro. Biol Reprod 12: 260-274.

Camous S, Heyman Y, Meziou W, Menezo Y (1984) Cleavage beyond the block stage and survival after transfer of early bovine embryos cultured with trophoblastic vesicles. J Reprod Fert 72: 479-485.
Davis DL (1985) Culture and storage of pig embryo. $J$ Reprod Fert, Suppl 33: 115-124.

Donahue RP, Stern S (1968) Follicular cell support of oocyte maturation. :Production of pyruvate in vitro. $J$ Reprod Fert 17: 395-398.

Eystone WH, First NL (1986) A study of the 8- to 16-cell developmental block in bovine embryos cultured in vitro. Theriogenology 25: 152 (Abstr).

Eystone WH, Vignieri J, First NL (1987) Co-culture of early bovine embryos with oviductal epithelium. Theriogenology 27: 228 (Abstr).

Eystone WH, First NL (1989) Co-culture of early cattle embryos to the blastocyst stage with oviducal tissue or in conditioned medium. $J$ Reprod Fert 85: 715-720.

Fukuda Y, Ichikawa M, Kubo K, Koike Y, Takami K, Ontani T, Toyoda Y (1987) Development to the blastocysts of bovine oocytes that matured and fertilized in vitro. Proc 79th Ann Meet Jpn Soc Zootech Sci pp 18 (Abstr) (in Japanese).

Fujitani Y, Shioya Y, Kuwayama M, Hanada A (1987) Study of in vitro development of bovine oocytes that matured and fertilized in vitro. Proc 72nd Ann Meet Jpn Soc Anim Reprod pp 17 (Abstr) (in Japanese).

Goto K, Kajihara Y, Kosaka S, Koba M, Nakanishi Y, Ogawa K (1988) Pregnancies after co-culture of cumulus cells with bovine embryos derived from in vitro fertilization of in vitro matured follicular oocytes. $J$ Reprod Fert 83: 753-758.

Goto K, Takuma Y, Ooe N, Ogawa K (1990) In vitro development of bovine oocytes collected from ovaries of individual cows after in vitro fertilization. Jpn J Anim Reprod 36: 110-113.

Hamberger L, Hillensjö T, Ahrén K (1978) Steroidogenesis in isolated cells of preovulatory rat follicles. Endocrinology 103: 771-777.

Henderson KM, McNatty KP, Smith P, Gibb M, O'Keeffe LE, Lun S, Heath DA, Prisk MD (1987) Influence of follicullar health on the steroidgenic and morphological characteristics of bovine granulosa cells in vitro. $J$ Reprod Fert 79: 185-193.

Heyman Y, Menezo Y, Chesne P, Camous S, Garnier V (1987) In vitro cleavage of bovine and ovine early embryos: improved development using co-culture with trophoblastic vesicles. Theriogenology 27: 59-68.

Jiang HS, Wang WL, Lu KH, McCarthy D, Gordon I (1989) In vitro culture of early bovine embryos derived from in vitro fertilization, comparison with in vivo culture. Proc Ann Conf Soc Study Fert pp 50 (Abstr).

Kajihara Y, Goto K, Kosaka S, Nakanishi Y, Ogawa K (1987) In vitro fertilization of bovine follicular oocytes and their development up to hatched blastocysts in vitro. Jpn J Anim Reprod 33: 173-180 (in Japanese).

Landefeld TD, Campbell KL, Midgley AR, Jr (1979) Rapid changes in the synthesis of specific ovarian granulosa cell proteins induced by human choriogonadotropin. 
Proc Natl Acad Sci USA 76: 5153-5157.

Nakao H, Suemori H, Nakatsuji N (1988) Effect of trophoblastic vesicles on the development of bovine embryos that fertilized in vitro. Proc 74th Ann Meet Jpn Soc Anim Reprod pp 34 (Abstr) (in Japanese). Schini SA, Bavister BD (1988) Two-cell block to development of cultured hamster embryos is caused by phosphate and glucose. Biol Reprod 39: 1183-1192.

Takuma Y, Goto K, Koba M, Tokumaru M, Nakanishi Y, Ogawa K (1989) Optimum number of oocytes derived from in vitro fertilization in the medium of development. Proc 76th Ann Meet Jpn Soc Anim Reprod pp 62 (Abstr) (in Japanese).

Thibault C (1966) La culture in vitro de l'ouef de vache. Annls Biol Anim Biochem Biophys 6: 159-164.
Tokunaga T, Tsunoda Y (1989) An overcoming of "in vitro 2-cell block" by co-culture with embryonal fibroblast cells in the mouse. Jpn J Anim Reprod 35: 119-124 (in Japanese).

Wang WL, Jiang HS, Lu KH, McCarthy D, Gordon I (1989) The effect of media and sera on the in vitro development of early bovine embryos. Proc Ann Conf Soc Study Fert pp 50 (Abstr).

Whittingham DG, Biggers JD (1967) Fallopian tube and early cleavage in the mouse. Nature 213: 942-943.

Yamada H, Sato T, Kitamura S, Shioya Y, Hanada A (1988) Developmental rates to blastocysts from oocytes derived from in vitro fertilization using epididymal or ejaculated spermatozoa in cattle. Proc 74th Ann Meet Jpn Soc Anim Reprod pp 67 (Abstr) (in Japanese).

\section{要 約}

牛の体外受精卵を用い，胚と卵丘細胞層の接触の有無が胚盤胞への発育に及ぼす影響を調べた。未 成熟卵を体外で20２4時間成熟させ，ヘパリンで受精能を獲得させた精子で媒精した。媒精72時間後 に, 卵丘細胞から卵子を外し，8-16細胞期胚のみを取り出した。 そして以下に示す 3 区に分けて，媒 精後 8 日間培養した．即ち，接触区：胚を卵丘細胞層の上において培養する。非接触区：肧を底面が フィルターの円筒形セルに入れ，このセルを卵丘細胞層の上において培養する. 非共培養区：培養液 のみで肧を培養する，2 種類の精子を用いて実験を行った結果，接触区，非接触区および非共培養区 に揖ける胚盤胞までの発育率（胚盤胞数/供試 8-16期肧数）はそれぞれ32.9 (23/70) 36.9\% (24/65)， $25.7(18 / 70) \sim 44.1 \%(30 / 68)$ および $7.4(5 / 68) \sim 9.2 \%$ (6/65) であり, 接触区と非接触区との間に は差がなく, 非共培養区で有意に低かった。これらの結果から, 卵丘細胞層は肧に直接接触していな くても発育促進効果があり, その作用発現には, 液性因子が関与していることが示唆された. 